\title{
Credit Dispute Resolution through Banking Mediation during Covid-19 Pandemic Situation
}

\author{
Bondan Seno Aji ${ }^{1}$, Made Warka ${ }^{2}$, Evi Kongres ${ }^{3}$ \\ ${ }^{1}$ Master Degree in Faculty of Law, Universitas 17 Agustus 1945, Surabaya, Indonesia \\ ${ }^{2,3}$ Lecturer in Faculty of Law, Universitas 17 Agustus 1945, Surabaya, Indonesia \\ bondan_bjtm@yahoo.co.id
}

\begin{abstract}
This study aims to find out credit dispute resolution through banking mediation in pandemic situation. This study use qualitative research method. The result shows that Settlement of bank credit problems that arose as a result of the Covid-19 pandemic, namely through deliberations between the bank (creditor) and the debtor. In POJK No.18 / POJK.07 / 2018 concerning Consumer Protection in the Financial Services Sector, it is stipulated that every financial service institution is required to have a work unit and / or function as well as a service and complaint resolution mechanism for consumers. If the dispute resolution at a financial service institution does not reach an agreement, consumers can resolve the dispute through the court or outside the court. Out of court dispute resolution is carried out through arbitration and alternative dispute resolution.
\end{abstract}

Keywords credit; banking mediation; covid-19

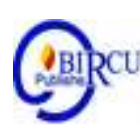

\section{Introduction}

During the Covid-19 pandemic, many people experienced a decline in income because the government imposed large-scale social restrictions (PSBB) and an economic recession. PSBB is regulated in Regulation of the Minister of Health of the Republic of Indonesia Number 9 of 2020 concerning Guidelines for Large-Scale Social Restrictions in the Context of Accelerating Handling of Corona Virus Disease 2019 (hereinafter referred to as Permenkes No.9 / 2020) and Government Regulation Number 21 of 2020 concerning Large-Scale Social Restrictions in the Framework Acceleration of Handling of Corona Virus Disease 2019 (hereinafter referred to as PP No.21/2020). Article 1 Permenkes No. 9/2020 concerning Large-Scale Social Restrictions are restrictions on certain activities of residents in an area suspected of being infected with Coronavirus Disease 2019 (COVID19) in such a way as to prevent the possible spread of Coronavirus Disease 2019 (COVID19). The application of Large-Scale Social Restrictions (PSBB) is one of the efforts of the Indonesian government to cut off and prevent the spread of the corona virus which is increasingly widespread in Indonesia. This PSBB will be implemented during the longest incubation period, 14 days. However, it does not rule out an extension of the PSBB period, if there is evidence of the spread of COVID-19. The application of Large-Scale Social Restrictions (PSBB) is one of the efforts of the Indonesian government to cut off and prevent the spread of the corona virus which is increasingly widespread in Indonesia. This PSBB will be implemented during the longest incubation period, 14 days. However, it does not rule out an extension of the PSBB period, if there is still evidence of the spread of COVID-19. The application of Large-Scale Social Restrictions (PSBB) is one of the efforts of the Indonesian government to cut off and prevent the spread of the corona virus which is 
increasingly widespread in Indonesia. This PSBB will be implemented during the longest incubation period, 14 days. However, it does not rule out an extension of the PSBB period, if there is evidence of the spread of COVID- 19.

The implementation of work from home, social distancing and PSBB adds difficulties to the business world. Difficulties experienced by the business world, one of which has an impact on the banking world, where many debtors experience financial difficulties so that they are unable to pay their credits. The inability or failure to pay from the debtor to the bank will result in an increase in non-performing loans and / or nonperforming loans which will have a negative impact on the banking sector. In general, companies, Micro, Small and Medium Enterprises (MSMEs) and individual businesses in fulfilling working capital needs to run a business make loans with financial institutions both banks and non-banks so that on the one hand they still have the obligation to pay off the loan while on the other hand they are trying to keep operating its business

A credit agreement (credit / loan agreement) is an agreement entered into between a bank and its debtor. A credit agreement can actually be likened to a debt agreement. The difference is, the term credit agreement is generally used by the bank as a creditor, while the loan-receivable agreement is generally used by the public and is not related to the bank. Credit can be classified into various categories. Types of credit, seen from their purpose, can be distinguished as follows:

1) Consumptive credit, namely credit provided with the aim of obtaining / buying goods and other necessities of a consumptive nature;

2) Productive credit, namely credit provided with the aim of smoothing the debtor's business;

3) Trade credit, which is credit given with the aim of buying goods to be sold again.

Prior to the COVID-19 pandemic, all business sectors experienced positive growth so that debtors still have the ability to pay debts smoothly, but there are also debtors who experience bad credit and / or credit problems which are usually due to declining, unstable business conditions, and other reasons in which the cases of bad credit and / or problematic debtors were not as many as at the time of the Covid-19 pandemic.

The debtor was initially able to carry out his obligations but due to an unexpected situation, namely the Covid-19 pandemic, he was forced to be unable to fulfill his achievement. In this context, it can be stated, for example, that the first time there is a compulsion, the debtor is still implementing it, but there are great sacrifices. In a different situation, the coercive situation exists, from the coercive situation that causes the debtor to be unable to carry out the credit agreement temporarily, and after the forcing situation disappears, the debtor can return to implementing the agreement. Exemptions from fees, losses and interest can also be obtained for parties who are faced with a situation of relative force majeure, but it does not end with the cancellation of the agreement. In relative force majeure, It can be understood that the exemption is only temporary in nature and as long as a force majeure condition prevents the debtor from making achievements. If the force majeure is gone, the creditor can demand achievement. The result of the relative force majeure is the temporary inability to implement achievements.

Force majeure is an event that occurs beyond the willing and ability of the parties, which causes losses to one of the parties. Apart from the force majeure, there is an overmacht definition and word. In the legal dictionary overmacht has the meaning of a state of force, which is a condition that prevents a person from carrying out an agreement that frees a person from the obligation to replace costs, losses and interest. The essence of this overmacht is that there is no fault of the party who does not fulfill his performance, thus causing a right or an obligation in a legal relationship to not be implemented. In a 
reciprocal agreement, the debtor cannot be deemed to have defaulted if there is a compelling situation where he cannot fulfill his performance.

To provide protection for both banks and debtors, the government implements a special policy in the banking sector, namely in the form of stimulus relaxation regarding restructuring, assessment of credit or financing quality and / or granting of new credit / financing with a multiplier effect policy resulting from the inability to pay debtors as a result of The Covid-19 pandemic is also an effort to stabilize the economy.

The government through the Financial Services Authority (OJK) issued a credit restructuring policy as stipulated in the Financial Services Authority Regulation Number 11 / POJK.03 / 2020 concerning Economic Stimulus as a Countercyclical Policy on the Impact of the Spread of Coronavirus Disease 2019 (hereinafter referred to as POJK No.11 / POJK.03 / 2020). Credit / financing restructuring in POJK No.11 / POJK.03 / 2020 can be carried out by reducing interest rates, extending the term, postponing arrears of principal and / or interest, adding credit / financing facilities, or converting credit / financing into temporary equity participation. awarded within a maximum period of 1 year. In providing credit relaxation stimulus to debtors in the form of credit restructuring or financing, banks must adhere to the prudential banking principle.

In practice, OJK gives freedom to banks in determining the credit restructuring scheme assigned to debtors. The determination of the scheme that is set depends on the bank's assessment of the debtor's financial performance as well as an assessment of the business prospects and capacity of paying debtors affected by the COVID-19 pandemic. The application for credit restructuring is made by a debtor affected by the COVID-19 pandemic submitting an application for restructuring first, after which the bank will conduct an assessment of the debtor's ability to pay based on the agreement of the parties.

Chairman of the OJK Board of Commissioners, Wimboh Santoso said that the trend of the ratio of non-performing loans (NPL) to banks increased slightly from time to time during the COVID-19 pandemic. According to him, OJK recorded the latest NPL figure in June at 3.11 percent. In fact, in December 2019, NPL was 2.53 percent, March 2020 was 2.77 percent, April was 2.89 percent, and in May was 3.01 percent. Meanwhile, the highest NPL occurred in working capital credit at 3.96 percent. After that followed by investment credit of 2.58 percent and consumption credit of NPL of 2.22 percent.

NPL is related to non-performing loans, not all banks have debtors who are diligent in paying their loans, but there are also debtors who are late in paying their loans, not only 1-2 months but for months. There are several types of debtors who apply for credit to the bank, the first type is a debtor who is diligent in paying his credit while the second debtor is a debtor who is not diligent in paying credit so that his credit is bad. Bad credit is what causes the NPL percentage ratio to increase dramatically. The pandemic also affected the ability to pay, which led to changes in the risk profile of debtors and led to an increase in NPLs. The potential for a spike in NPLs and defaults still needs to be watched out for, because the

COVID-19 restructuring stimulus facility, which is the solution, is not quite evenly distributed for all debtors. One of the example, there are debtors who only get credit stimulus relaxation for three months or six months. The form of relief is according to the policies of each bank. Not to mention that there are debtors whose restructuring was not approved because banks strictly apply the principle of prudence in providing relaxation of credit stimuli to reduce the level of the NPL ratio. 


\section{Review of Literature}

\subsection{Theory of Legal Justice}

Justice is one of the most discussed objectives of law throughout the history of legal philosophy. The purpose of law is not only justice, but also legal certainty and legal benefits. Ideally, the law must accommodate all three. The judge's decision, for example, is as far as possible the resultant (result) of the three. Even so, there are those who argue that among the three purposes of law, justice is the most important goal of law, and some even argue that justice is the only goal of law.

Ulpianus, describes justice as justitia constans et perpetua voluntas ius suum cuique tribuendi (justice is the will that continues and still gives to each what is due), or tribuere cuique suum-to give everybody his own, justice gives to everyone which is due. This formulation firmly recognizes the rights of each person to another, as well as what should be part of it, and vice versa.

Friedman distinguished justice according to law, and justice according to nature. Natural justice is justice whose effectiveness is not influenced by space and time, and its existence is not the result of public thought. Legal justice is justice who is originally not different, but when it has been used as a basis, it will be different.

Thomas Aquinas distinguishes justice between two groups, namely general justice (iustitia generalis) and special justice (iustitia specialis). General justice is justice according to the will of the law, which must be fulfilled in the public interest. Furthermore, special justice is justice based on equality or proportionality. This special justice can be divided into:

1. Distributive justice (distributive iustitia);

2. Commutative justice (iustitia commutativa);

3. Vindicative justice (iustitia vindicativa).

Aristotle said justice was understood in terms of equality, but made an important distinction between numerical equality and proportional equality. Numerical similarities equate each human being as one unit. This is what we now usually understand about equality and what it means when it is said that all citizens are equal before the law. Proportional equality gives each person what is due according to his abilities, achievements and so on.

Aristotle distinguishes justice into distributive justice and corrective justice. Distributive justice applies in public law, corrective justice in civil and criminal law. Distributive justice states that equal rewards are given for equal gains. Meanwhile, corrective justice, which becomes a problem is that inequality caused by, for example, a violation of the agreement, is corrected and eliminated. Distributive justice according to Aristotle focuses on the distribution, honorarium, wealth, and other goods that can be found in society.

Natural law theory prioritizes "the search for justice", various kinds of theories about justice and a just society. These theories concern rights and freedoms, power opportunities, income and prosperity. Among these theories can be called: Aristotle's theory of justice in his book Nicomachean ethics and John Rawls's theory of social justice in his book a theory of justice and Hans Kelsen's theory of law and justice in his book general theory of law and state.

Several concepts of justice put forward by the American philosopher in the late 20th century, John Rawls, such as A Theory of Justice, Politcal Liberalism, and The Law of Peoples, have had a considerable influence on the values of justice. John Rawls, who is seen as a "liberal-egalitarian of social justice" perspective, argues that justice is the main 
virtue of the presence of social institutions. However, policies for the whole of society cannot exclude or challenge the sense of justice of everyone who has obtained a sense of justice. Especially weak people who seek justice.

\subsection{The Theory of Will (Wilstheorie)}

Freedom of the will is the individual's ability to decide and act with full control without external coercion. The issue of freedom of will arises around the debate between camps that believe in free will and those who reject the existence of free will (determinism). Griffin's thinking consists of process theology and postmodern theology.

Process theology bbased on the concept of process, contentment, essential connectedness, incarnation, creative self-determination, creative self-expression, newness, and connectedness of God. Meanwhile, postmodern theology is a critique of two stages of the modern worldview which is dualistic supernaturalistic and materialistic atheistic by promoting a constructive postmodern vision based on anti-individualistic spirituality, organizationalism, traditionalism, transformative, naturalistic and postpatriarchal panentheism.

Griffin's concept of free will is divided into cosmological, theological and axiological freedom. Cosmologically, humans have a high level of freedom because the dominant soul pole in humans has the ability to make free self-determination. Axiologically, humans have the freedom to actualize ideal values based on sympathy and pluralism that reject absolute truth claims, reject the equality of all religions, and prioritize deep dialogue in this life.

Agreement is reached through a meeting of a statement of the will, then the element of the will and the statement of the will is the main elements, in addition to other elements that determine the birth of an agreement. If the will is stated correctly, then the statement will be in accordance with the will. It's just that, often people say something is not according to what they want. In other words, the statement addressed to the opponent of his promise is not in accordance with what he wants.

According to the theory of the will that determines the occurrence of an agreement is the will of the parties. A binding agreement, if the two wills have met each other and the agreement is binding on the basis that the will of the parties should be respected. Thus, the theory of will has the principle that an agreement which is not based on a right will is invalid. This will theory is the basis for the formation of the Civil Code.

\subsection{Legal Protection Theory}

The government that represents the state, as is the goal of the state itself, the government must ensure the implementation of rights and obligations, as well as to protect all nations in a country and to realize social justice for all the people of that country is included in the meaning of legal protection. The theory of legal protection on the grounds that the law protects the interests of a person by allocating his power to him to act in his interests and that is a right target.

Fitzgerald explained: "That the law aims to integrate and coordinate various interests in society by limiting the variety of interests such as in a traffic interest on the other" (that law aims to integrate and coordinate shared interests in society by limiting these various interests because in traffic of interest, protection of said interest can only be done by limiting the interests of the other party).

Legal protection that is pursued through legislation has legal principles underlying it. Likewise, legal protection that is pursued through the creation and inclusion of steps through legislation that has a purpose and scope is planned through strategy and policy. All 
of these things can be found in any legislation which is mainly held with the same objective, namely legal protection. Roscoe Pound classifies interests protected by law into 3 (three) main categories, including:

1. Public interests (public interests);

2. Social interests (social interests);

3. Personal interests (private interests).

Rights are powers that are given by law to a person with a close relationship between rights and obligations, the right to pair with obligations, "meaning that if someone has rights, then his partner is an obligation to another person". Rights are something inherent in humans by nature and because of this right, law is needed to maintain the continuity of the existence of rights in the pattern of social life and because of this right, the law was created. These interests are not created by the state because these interests already exist in social life and the state only chooses which ones to protect.

According to Peter Mahmud Marzuki there are 3 (three) elements to a right, namely: an element of protection, an element of recognition and an element of will. Protection is an important element in rights, as in Houwing's opinion sees "rights as an interest protected by law in a certain way." The law must consider interests carefully and create a balance between them. Van Dijk in Peter Mahmud Marzuki states that "the law must function in achieving the goal of peace, the goal of achieving peace can be realized if the law provides as many fair arrangements as possible".

Likewise, all kinds of risks can be endeavored to be prevented by filing through clauses which are packaged on the basis of agreement too, so that with this clause the parties will receive balanced legal protection with their mutual consent. Regarding internal legal protection as such can only be realized by the parties, when their legal position is relatively equal in the sense that the parties have relatively balanced bargaining power, so that on the basis of the principle of freedom of contract, each partner in the agreement has the freedom to state his will according to his interests. This pattern is used as a basis when the parties prepare agreement clauses, so that the legal protection of each party can be realized straightforwardly on their initiative. External legal protection made by the authorities through regulation for the interests of the weak, in accordance with the nature of the laws that are not biased and partial, and proportionally must also be given balanced legal protection as early as possible to other parties. Because it is possible that at the beginning of the agreement, there is a party that is relatively stronger than the partner, but in the implementation of the agreement, the party that was originally strong will fall into the persecuted party, namely when the debtor defaults, the creditor should also need legal protection. Packing of statutory rules Proportionately also obliged to be given equal legal protection as early as possible to other parties. Because it is possible that at the beginning of the agreement, there is a party that is relatively stronger than the partner, but in the implementation of the agreement, the party that was originally strong will fall into the persecuted party, namely when the debtor defaults, the creditor should also need legal protection. Packing of statutory rules Proportionately also obliged to be given equal legal protection as early as possible to other parties. Because it is possible that at the beginning of the agreement, there is a party that is relatively stronger than the partner, but in the implementation of the agreement, the party that was originally strong will fall into the persecuted party, namely when the debtor defaults, the creditor should also need legal protection. Packing of statutory rulesas outlined it is illustrated how detailed and fair the ruler provides legal protection to the parties proportionally. Issuance of legal regulations with such a model, of course, is not an easy task for a government that always tries optimally to protect its people. 


\section{Results and Discussion}

In general, civil dispute resolution can be carried out in various ways, including: arbitration, negotiation, mediation, conciliation and litigation. Settlement of disputes by mediation is currently limited to disputes in the civil sector. This is due to the view that the dispute is not detrimental to society in general. In Indonesia, there are several disputes that can be resolved by mediation, namely disputes in the banking sector, consumers, labor, and disputes in court.

The existence of alternative dispute resolution is expected to reduce the number of cases that have accumulated in court and can provide a sense of justice for the community. The occurrence of a dispute between the parties, gives options to each party to choose the method that will be used to solve the problem. Each party can choose through the court or outside the court.

In general, dispute resolution through the courts is pursued based on the initiative of one of the parties. Meanwhile, settlement of disputes outside the court can only be pursued by the parties based on the agreement of the parties, in other words there is good faith from each party. Unlike arbitration, the decisions of the arbitrator or arbitration panel must be obeyed by the parties, just like a court decision. Meanwhile, in mediation, there is no obligation on the part of each party to obey what the mediator says. In mediation the parties are able to control the outcome.

The requirements for successful mediation are:

1. The parties have the desire to settle the case.

2. The parties want to continue in business.

3. Realization that litigation is time consuming, expensive and costly to publicize.

4. A good mediator, can facilitate communication between the two parties, is fair.

5. Have expertise in solved cases.

Some of the advantages of mediation are:

1. Agreement of the parties (voluntary)

2. Maintained good relations (forward looking)

3. Maintaining the interests of each party

4. The process is cheap, fast and simple

Therefore, holding mediation for the disputing parties will help to:

a. Reducing barriers and communication problems between the parties involved.

b. Maximization of exploration for alternative solutions to long-term problems / conflicts.

c. Focus on the needs of all parties.

d. Build long-term conflict resolution models.

The world of banking has a very important role for society. This role is to store and channel funds to the community. A bank certainly has a predetermined system regarding services to its debtors. However, it is possible that the services provided by the bank to its debtors will not provide satisfactory results for the debtors so that the debtors often feel disadvantaged.

Debtors often become helpless when they have to deal with banks in court and can only surrender when disputing with the bank. Debtors who have disputes with banks regarding bank credit can be resolved out of court. In order for debtors to be protected by their rights, a bank mediation was formed which functioned as a dispute resolution institution. In resolving the dispute, the parties, namely the bank and the debtor, are mediated by a neutral party, namely Bank Indonesia. This is so that debtors can protect their rights as debtors. 
The emergence of initiatives regarding the settlement of banking disputes through mediation came for the first time from Bank Indonesia, to regulate the formation of banking mediation institutions. Then in 2006 Bank Indonesia through Bank Indonesia Regulation Number: 8/5 / PBI / 2006 concerning Banking Mediation (hereinafter referred to as PBI concerning Banking Mediation), in Article 3 paragraphs (1) and (2) has mandated the establishment of an independent banking mediation institution which a banking association shall be formed by December 31, 2007. Furthermore, Article 3 paragraph (4) of the PBI on Banking Mediation states that as long as an independent banking mediation institution has not been established, the banking mediation function is carried out by Bank Indonesia. However, until 2008 the independent banking mediation institution mandated by the PBI for Banking Mediation had not yet been formed.

This forced Bank Indonesia to amend the PBI for Banking Mediation. Banking mediation as an alternative to banking dispute resolution is a simple, inexpensive, and fast way to resolve problems that occur between debtors and banks. In addition, the result of mediation, which constitutes an agreement between the debtor and the bank, is seen as an effective form of problem solving because the debtor's interests and the bank's reputation can be safeguarded.

Banking mediation that is a requirement for banking disputes is as follows:

a. Submitted in writing by debtors / debtor representatives, accompanied by supporting evidence.

b. An attempt has been made to resolve it with a bank

c. It is not in the process or has never been decided by an arbitration institution or judiciary or there has been no agreement facilitated by other mediation institutions.

d. Civil disputes that have the potential to cause debtor financial losses, allegedly due to bank error or negligence.

e. The maximum financial demand is IDR 500,000,000 (five hundred million rupiah) and is not an immaterial loss.

f. It has never been processed in banking mediation by Bank Indonesia.

g. Received a maximum of 60 (sixty) calendar days from the date of the results letter

h. Resolution of complaints submitted by the bank to the debtor.

The provisions of Bank Indonesia Regulation Number: 8/5 / PBI / 2006, in Article (1) point 5 stated that mediation is a dispute resolution process that involves a mediator to assist the disputing parties to reach a settlement in the form of a voluntary agreement on some or all of the disputed issues. The agreement is set forth in an agreement deed, which is a written document that contains a final and binding agreement for the debtor and the bank. Meanwhile, the mediator is the party who does not take sides in assisting the implementation of mediation.

The dispute settlement mechanism in the form of mediation applies the principles of accessibility, independence, fairness, and efficiency and effectiveness. The debtor protection system will increase debtor's trust in banks and have a positive impact on the development of the banking industry in realizing a financial system that grows continuously and is stable.

From the explanation above, credit disputes experienced by debtors and banks indicate that the method of mediation is more suitable for debtors and banks to choose rather than resolve disputes through court or arbitration, because of the Covid-19 pandemic conditions, of course, there are many limitations to the parties, if through the court, you have to come over and over again. Times in court, convoluted, costly, and time consuming. Meanwhile, if through mediation the process is faster, cheaper, simpler and good relations are maintained between the debtor and the bank. 


\section{Conclusion}

Settlement of bank credit problems that arose as a result of the Covid-19 pandemic, namely through deliberations between the bank (creditor) and the debtor. In POJK No.18 / POJK.07 / 2018 concerning Consumer Protection in the Financial Services Sector, it is stipulated that every financial service institution is required to have a work unit and / or function as well as a service and complaint resolution mechanism for consumers. If the dispute resolution at a financial service institution does not reach an agreement, consumers can resolve the dispute through the court or outside the court. Out of court dispute resolution is carried out through arbitration and alternative dispute resolution. The appropriate mechanism for out-of-court dispute resolution related to bad credit and / or non-performing loans is through mediation.

\section{References}

Aaron Badriyah, Credit Problem Solving. Yogyakarta: Yustisia Reader, 2010

Amir Machmud Rukmana, Islamic Bank (Theory, Policy, and Empirical Studies in Indonesia), PT. Gelora Aksara Pratama, Jakarta, 2010

Andi Hamzah, Legal Dictionary, Jakarta: Ghalia Indonesia, 1986

Ahmadi Miru, Contract Law and Contract Design, Rajawali Press, Jakarta, 2007

Ahmadi Miru and Sakka Pati, Bond Law: Elucidation of Articles 1233 to 1456 BW, Raja Grafindo Persada, Jakarta, 2012.

Arthesa, Ade, Bank and Financial Report Analysis of Non-Bank Financial Institutions, PT INDEX Gramedia Group: Jakarta, 2006

Bodenheimer in Satjipto Rahardjo, Law Science, Bandung: PT. Citra Aditya Bakti, 2006

Carl Joachim Friedrich, Historical Perspective Philosophy of Law, Nuansa and Nusamedia. Bandung. 2004

Cowburn, John, 2008, Free Will, Predestination and Determinism, Marquette University Press, Milwaukee-Wisconsin

Ferry N. Idroes, Banking Risk Management Understanding the Basel II Agreement Pillar Approach, Jakarta: PT. Raja Grafindo Persada, 2008

Ferry N Idroes, Banking Risk Management, Understanding the 3 Pillar Approach of the Basel II Agreement Regarding Regulation Application and Its Implementation in Indonesia, PT. Raja Grafindo Persada, Jakarta, 2008

Frank Taira Supit, "Legal Aspects of the" Loan Agreement "in the World of International Business", Symposium on Legal Aspects of Credit Issues (Jakarta: National Legal Development Agency, Ministry of Justice, 1985)

FX Djumialdji, Building Law Legal Fundamentals in Human Resources Projects,

Griffin, David Ray, Evil Revisited: Responses and Reconsiderations, State University of New York Press, Albany, 1991

Handri Raharjo, Agreement Law in Indonesia, Pustaka Yustisia, Yogyakarta, 2009

Hans Kelsen, General Theory of Law and State ", translated by Rasisul Muttaqien, Bandung, Nusa Media. 2011

Hans Kelsen, 'Pure Legal Theory The Basics of Normative Law', Bandung: Nusa Media, 2008

HR Otje Salman, S, Philosophy of Law (Development \& Dynamics of Problems), Bandung: PT. Refika Aditama

Irfan Fahmi, Risk Management, Theory, Cases and Solutions, Alfabeta, Bandung, 2011 
J. Satrio, Law of Guarantee of Property Guarantee Rights, Citra Aditya Bakti, Bandung, 2007 ,

Johannes Ibrahim and Lindawaty Sewu, Business Law in a Modern Human Perspective, PT. Refika Aditama, Jakarta, 2004

John Rawls, A Theory of Justice, London: Oxford University press ", which has been translated into Indonesian by Uzair Fauzan and Heru Prasetyo, Theory of Justice, Student Library. Yogyakarta. 2006

JP. Frtzgerald, Salmond On Jurisprudenc E, sweet \& Mazwell, London, 1966, p. 53

Karim Riduan, Principles of Risk Management, Iqtisad Journal, Bandung, 2004

Kasid, Risk Management, Ghalia Indonesia, Bogor, 2010

Cashmere, Entrepreneurship, Revised Edition cet 8, Rajawali Pers, PT. Rajagrafindo Persada, Jakarta, 2013

, Banking Basics, Jakarta: PT Raja Grafindo Persada, 2008

, Banks and Other Financial Institutions, Revised Edition, Jakarta: PT Raja Grafindo Persada, 2008

LJ Van Apeldoorn, "Introduction to Legal Studies", printed thirty-sixth Pradnya Paramita, Jakarta. 2018

Lili Rasjidi and IB Wyasa Putra, Law as a System, Youth Rosdakarya, Bandung, 1993

M. Yahya Harahap, Legal Aspects of Engagement, PT. Alumni, Bandung, 1982

Moch. Isnaeni, Introduction to Material Guarantee Law, PT. Revka Petra Media, Surabaya, 2016

Muhtadi, 'The Application of Hans Kelsen's Theory in Indonesian Law Order', Fiat Justisia, 2017.

Munir Fuady, Contract Law: From a Business Law Point of View, Citra Aditya Bakti, Bandung, 2001,

O. Notohamidjojo, Justice Issues, Tirta Amerta, Semarang, 1971, pp. 18-19.

Permadi Gandapradja, Basics and Principles of Bank Supervision, PT. Gramedia Pustaka Utama, Jakarta, 2004

Peter Mahmud Marzuki. Legal Research. Kencana, Jakarta, 2010.

Philipus M. Hadjon, The Study of Law, Research Papers of Normative Law Research Methods, Airlangga University, Surabaya, 1997

PNHSimanjuntak, Principles of Indonesian Civil Law, Djambat, Jakarta, 2009

Qirom Syamsudin Meliala, Principles of Agreement Law, ctk. First, Liberty, Yogyakarta, 1985

R. Subekti, Various Agreements, PT. Alumni, Bandung, 1984

Rachmat SS Soemadipradja. Explanation of the Law on Forceful Situation. Gramedia Jakarta 2010.

Rachmat F \& Maya A, Commercial Bank Credit Management: Theory, Policy Problems and Its Application, Bandung: Alfabeta, 2008

Satjipto Rahardjo, Law Science, Citra Aditya Bakti, Bandung, 2000

Sonny Keraf, Business Ethics Guidelines and Their Relevance, Kanisius, Yogyakarta, 1998

Sudikno Mertokusumo, Knowing the Law (An Introduction), Liberty, Yogyakarta, 1995

Sutarno, Legal Aspects of Credit in Banks, Alfabeta, Jakarta 2003.

Subekti, Agreement Law, Intermasa, Jakarta, 1987.

Principles of Civil Law. PT.Intermasa, Jakarta, 1998.

Agreement Law, Citra Aditya Bakti, Jakarta, 2015. 